\title{
Why Does the Japanese Constitution not Include the Creation of a Special Tribunal?
}

\author{
Yuichiro Tsuji ${ }^{(1)}$
}

\begin{abstract}
Nowadays, it is observed that court systems of other countries are establishing new extraordinary tribunals such as environmental law court or intellectual property (IP) court. These specialized courts are presided by judges who have acquired special training and knowledge that renders them flexible solutions. It is purported that a judge in this extraordinary court offers speedier decisions and remedies than a tenured general judge in a general court.
\end{abstract}

However, Japan faces certain obstacles in the creation of such extraordinary tribunals owing to the content of its Constitution. Article 76 of the Japanese Constitution clearly stipulates the following: "The whole judicial power is vested in a Supreme Court and in such inferior courts as are established by law. No extraordinary tribunal shall be established, nor shall any organ or agency of the Executive be given final judicial power. All judges shall be independent in the exercise of their conscience and shall be bound only by this Constitution and the laws. No extraordinary tribunal shall be established."

This article raises a few important questions: Why did the Japanese Constitution mention such a prohibition in text? How the family court and IP

(1) Yuichiro Tsuji, Faculty of Law, at Surugadai University. S.J.D. University of California, Berkeley School of Law in 2006. 
court in the existing Japanese court system were created by the interpretation of Article 76. Moreover, were these courts prohibited from becoming an extraordinary tribunal of the Constitution?

In this paper, I attempt to answer these questions by analyzing the history of the drafting of the Japanese Constitution post World War II as well as the present-day interpretation of Article 76 .

\section{Overview of Japanese court system}

\section{Impeachment Court under the Japanese Constitution}

The Japanese Constitution states that there is one court in which the person who hears cases is not a professional judge from the judiciary. Article 64 states that "The Diet shall set up an impeachment court from among the members of both Houses for the purpose of trying those judges against whom removal proceedings have been instituted. Matters relating to impeachment shall be provided by law."

In this impeachment court, judges are selected from among the members of the Diet. From the viewpoint of separation of powers, the members of the Diet hear the case for the removal of the judges. This is an exception in the text of the Japanese Constitution. ${ }^{(2)}$

\section{Constitutional Court in Japan}

According to the Japanese Constitution, an extraordinary tribunal does not imply that the court has exclusive jurisdiction over constitutional issues. Like the U.S. court system, the Japanese court system does not have an independent constitutional court separated from a general court system. In Germany, South Korea, Taiwan, and Thailand, a special constitutional court exists, which exercises judicial review over some constitutional issues.

In Germany for instance, there are some types of judicial reviews carried

(2) Kokkai hou (Law of the Diet), Article 125-129. And The Law of Impeachment of the Judge, Article 2-5. Ten members are selected from the House of Representatives and the House of Councilors. 
out by the German Federal Constitutional Law Court under the "Federal Constitutional Court Act (Bundesverfassungsgerichts-Gesetz, BVerfGG).”

The first type in the procedure of a judicial review is the filing of constitutional complaint (Verfassungsbeschwerde). The cases presented in this court are against public organizations such as administrative agencies or the government. Since anyone is free to file this complaint, thousands of complaints are sent to the Federal Constitutional Law Court every year. However, only some complaints are selected for review by the court. The court decides if the complaints presented to it involve important issues related to constitutional law. The Federal Constitutional Court only reviews whether or not human rights are infringed. Other legal issues are to be heard in other courts.

The second type involves conducting proceedings on the constitutionality of statutes. In Germany, only the Federal Constitutional Court takes decisions on matters of constitutional law. If inferior courts believe that the case pertains to any constitutional issue, it is the judge's duty to forward this case to the Federal Constitutional Court. This step is called the concrete review of statutes.

The third type is called abstract review of statues. In this type, the party that can file a complaint is limited to the federal government, a state government, or one-third of the members of the federal Diet (Bundestag).

The fourth type in the judicial review process is the resolution of constitutional disputes between state and federal government. There are occasional conflicts between the Länder (federal states) and the Federation. with regard to constitutional issues. The proceedings on a dispute between the state and federal bodies are called Organstreit proceedings. Generally, this dispute deals with competency issues of their authorities. Questions pertaining to the constitutionality of political parties are heard in this procedure as well.

The German Federal Constitutional Court adopted a new system after the failure of the Nazi court during WWII. While the Federal Constitutional Court only hears matters pertaining to constitutional law in Germany post WWII, the Japanese court system followed the model of the U.S. Constitution. 
No special constitutional court outside the judiciary was adopted in the Japanese court system. In fact, the Japanese Supreme Court in addition to the inferior courts is allowed to exercise judicial review.

\section{3 . Japanese Court System}

In Japan, there is only one Supreme Court in Tokyo, which is the final and highest court in the hierarchy of the court systems. One chief justice and fourteen justices work for the Supreme Court. The chief justice is nominated by the prime minister and appointed by the Emperor. ${ }^{(3)}$ Other justices are appointed by the prime minister. In the inferior courts, judges are appointed by the Cabinet from the assignment list made by the Supreme Court.

Besides the Supreme Court in Tokyo, there are eight high courts in the major cities of Sapporo, Sendai, Tokyo, Osaka, Nagoya, Hiroshima, Takamatsu, and Fukuoka. Each high court exercises its power over one of the eight geographic areas of Japan. High courts work as appeal courts from the district courts in the first instance and family courts. Moreover, high courts have original jurisdiction over administrative cases filed against the government.

\section{Three Instances System}

In the judicial hierarchy, there are three instances: one Supreme Court, high courts, district courts, family courts and summary courts. Fifty district courts have jurisdictions in the assigned territorial areas. We have 47 prefectures in Japan. With the exception of Hokkaido, district courts exercise their power on each prefecture where they are located. Hokkaido is so huge that it is divided into three parts. The district court is the first instance court, except in the case of exclusive jurisdiction of other courts.

Family courts hear cases of domestic relations and juvenile delinquency. They are the first instance courts for all family dispute cases. However, the family court is not defined as an extraordinary tribunal, which is prohibited

(3) Article 6 and 66 of the Japanese Constitution. Prime minister is appointed by emperor after designated in the Diet (Parliament). 
in Article 76, as I will explain in the chapter IV.

Family courts are located all over Japan. Fifty family courts are located in the same place where district courts are located, and other seventy-seven branches of family courts deal with family-related issues.

Summary courts are the first instance courts, found in 438 places in Japan. They hear the case that the claim is less than 1,400,000 yen in civil cases. Summary courts hear criminal cases for offenses punishable by fines or lighter punishments, such as theft and embezzlement.

In this hierarchy, the losing party in the court may appeal to challenge at three different instances. Criminal cases taken up at a summary court goes directly to the high court, while civil cases starting at the summary court usually go to the district court. If the case is heard in the district court, the final court is the highest court, namely, the Supreme Court.

II. Why Is There No Special Court in Japan? History of Meiji Constitution

1. Article 76 in Chapter VI of the Japanese Constitution

The current Japanese Constitution has 103 articles, and the establishment of an extraordinary tribunal is clearly prohibited in Article 76 , Chapter $6 .{ }^{(4)}$ Article 76 in Chapter 6 "Judiciary" stipulates that the entire judicial power is solely vested in the Supreme Court and in such inferior courts as are established by law. No extraordinary tribunal shall be established, nor shall any organ or agency of the Executive be given final judicial power. There is a unique history behind Article 76 in the Japanese Constitution. However, before looking at the drafting history, the Japanese Constitution of the Empire of Japan should be reviewed.

(4) Japanese Constitution has eleven chapters; The Preamble, I. The Emperor, II. Renunciation of War, III. Rights and Duty of the People, IV. The Diet, V. The Cabinet, VI. The Judiciary, VII. Finance, VIII. Local Self-Government, IX. Amendments, X. Supreme Law, XI. Supplementary Provisions. 


\section{Meiji Constitution}

The Japanese Constitution of the Empire of Japan, hereinafter called the Meiji Constitution, was in effect from 1890 to $1946{ }^{(5)}$ In Article 60 of the Meiji Constitution, Chapter 5 on judiciary provided that the jurisdiction of a extraordinary court may be established by the law. Article 61 approved the administrative court that had exclusive jurisdiction over certain administrative cases.

Under the Meiji Constitution before WWII, the Japanese court followed the European model of the court system. Moreover, unlike the present Japanese Constitution, judicial review was not allowed ${ }^{(6)}$ In the Meiji Constitution, the term "tribunal" referred to the court which heard only civil and criminal cases, excluding administrative cases. In this Constitution, the highest court in the hierarchy was the sole Supreme Court (Dai Shin in). ${ }^{(7)}$

The administrative court was established and it was the first, final, and exclusive court for administrative cases. The authority of the administrative court was stipulated in the statutes. Only enumerated powers in the statutes were allowed to be exercised in the administrative court; implied power was not allowed. Because remedy in the administrative court was limited even in the period of the Meiji Constitution, the bills of revision for administrative courts were sent to the Imperial Diet several times. However, all these bills failed. Under the Meiji Constitution, the administrative court coexisted with the general court system as the highest court. The issue of conflict between the general court and administrative court arose many times. ${ }^{(8)}$

(5) 1889 for proclamation, 1890 in force.

(6) One decision in 1913 held that under Meiji Constitution judicial review was not allowed.There is no provision of judicial review in Meiji Constitution.

For operation of Meiji Constitution, Makoto OHISHI, Nihon Kenpo Si (Yuhikaku 1995), (hereinafter, OHISHI) 229-258. See also, Hitoshi KITAHARA, Assemblies of the Estate Constitutionalism (1)-(8), 22 Surugadai Journal of Law and Politics 1.

(7) Tatsukichi MINOBE, Kenpo Teiyo (revised version) (Yuhikaku 2000), 506. (hereinafter, MINOBE). 
Under the Meiji Constitution, there were other extraordinary tribunals such as military court, royal court, colonial court, and IP court. The royal court, for example, is independent of the general court system. The statutes for the royal family were as high as the Meiji constitutional law. These extraordinary tribunals were special courts that exercised exclusive jurisdiction independent of the general court system during the Meiji Constitution.

3. Tatsukichi Minobe and the Meiji Constitution

Professor Tatsukichi Minobe was a famous Meiji constitutional law professor. He provided some explanations for extraordinary tribunals under the Meiji Constitution. According to him, extraordinary tribunals were established by law and allowed to exercise jurisdiction under the Meiji Constitution. These tribunals were separated from the general court hierarchy. Generally, judges at extraordinary tribunals were not independent judges with a tenured position but administrative officers in most cases. ${ }^{(9)}$

For example, some judges in military courts were tenured civilians or high-ranking military officers. The president of the military court was the Minister of Army. These judges were independent, and attorneys were not allowed to be with the defendants. Moreover, the losing party could not appeal, which meant that the decision rendered was final.

In the military court, criminal cases of soldiers and sailors were heard. Except cases for the treaty for war prisoners, all people who served in the army and navy were under the jurisdiction of this military court. Civilians were also summoned to the military court in order to maintain peace and order in the military. ${ }^{(10)}$

In the IP court, IP cases were heard. The most procedures are as same as those of civil cases. Unlike the military court, the losing party was allowed to

(8) MINOBE, at 506-511. See also, Tatsukichi MINOBE, Gyoseiho-Teiyo (Jou) (12 th edition) (Yuhikaku 1925), 646-48. (Conflict of the jurisdiction between administrative and judicial court)

(9) Id.

(10) Id. At 502-503. 
appeal to the Supreme Court in IP cases. ${ }^{(11)}$

A unique characteristic of the Meiji Constitution was that it had an administrative court. ${ }^{(12)}$ This court was fundamental to the Constitution. The administrative court belonged to the executive power and not the judiciary. While the Japanese had the right to access the court in the judiciary according to Article 24 of the Meiji Constitution, they were not granted access to the administrative court. Both the judiciary court and administrative court had the jurisdiction to decide which cases belonged to either the administrative court or the judicial court. The decisions by both courts were exclusive and bound the other court. However, there was no available law in case the decisions by both courts were in conflict. Thus, several bills for reform of administrative courts were deliberated. ${ }^{(13)}$

In this chapter, I discuss the Meiji Constitution. After the atomic bombings in Hiroshima and Nagasaki and the acceptance of the Potsdam Declaration, the Japanese government worked with the General Headquarters (GHQ) to draft the current Japanese Constitution. In the next chapter, I will examine several constitutional drafts around 1946 immediately following WWII.

\section{Draft of New Japanese Constitution}

1. Draft of Present-day Japanese Constitution: Why Prohibit the Extraordinary Tribunal?

In this chapter, I will explain the history of the Japanese Constitution, focusing on extraordinary tribunals. ${ }^{(14)}$ There were several drafts drawn up for the Japanese Constitution on August 15, 1945. Apart from the government, although some private organizations formulated some drafts, I focus on governmental drafts in this paper. ${ }^{(15)}$

After accepting the Potsdam Declaration, the Japanese government was
(11) Id. At 503-504.
(12) Article 61 of the Meiji Constitution.
(13) MINOBE, at 509-511. See also, OHISHI, at 249. 
under the rule of the GHQ, that is, the Supreme Commander for the Allied Powers. The Japanese government had the first draft written by Joji Matsumoto, the chief director of the Constitutional Problems Investigation Committee (Matsumoto Committee), who acted as the Minister of State. Matsumoto maintained the main principles of the Meiji Constitution, such as sovereignty of the emperor. ${ }^{(16)}$

2. Draft of the Japanese Constitution

On February $1^{\text {st }}$ in 1946, the Mainichi newspaper received information about a draft of the Japanese Constitution made by Matsumoto. The GHQ read this old-fashioned draft in the newspaper, and General Douglas MacArthur directed Courtney Whitney, Chief of Government Section at GHQ, to consider a new Constitution for the Japanese. On February $3^{\text {rd }}$, the "MacArthur Note" was presented to MacArthur. ${ }^{(17)}$ This note contained three principles. ${ }^{(18)}$ Consequently, Whitney worked on a new draft of the Constitution called the "MacArthur Draft."

On February $13^{\text {th }}$, Whitney presented the new draft at a meeting held with Matsumoto and the Minister for Foreign Affairs, Shigeru Yoshida. Matsumoto and Yoshida were surprised to hear that the "Matsumoto Draft" was instantly rejected and the "MacArthur Draft" was handed to them. ${ }^{(19)}$

On returning from GHQ, the Japanese government was troubled on reading this draft. Following a discussion, on February $22^{\text {nd }}$, it was decided to formulate a new draft accepting the instruction of the GHQ. Officer Tatsuo Sato, Director of the First Department in the Bureau of Legislation, and Toshio Irie, Vice Director General in the Bureau of Legislation worked on this new

(14) Toshiyuki NISHIKAWA, The Future of the Japanese Constitution: From the "MacArthur Constitution" to What?, 17 Comparative Law and Culture 51 (2009). See also, Nobuyoshi ASHIBE, Kazuyuki TAKAHASHI, Katsutoshi TAKAMI, Tutomu HIBINO, Nihonkoku Kenpo Seitei Siryo Zenshu (4)-1 (Shinzansha 2008). (15) Id.

(16) Tatsuo SATO, revised by Isao SATO, Nihon Koku Kenpo Seiritsu si, Volume 3 (Yuhikaku 1994), 138, 266-269. (hereinafter, Isao SATO). 
draft from February $27^{\text {th }}$ onward. ${ }^{(20)}$

On March $2^{\text {nd }}$, the new draft was completed, and it was called "the March 2 Draft". Matsumoto and Sato brought this draft to the GHQ in the morning of March $4^{\text {th }}$. On March $5^{\text {th }}$, most of the consideration with GHQ were completed. On $6^{\text {th }}$ of March, this draft was published as the "Outline of a Draft for a Revised Constitution (Kenpo Kaisei Souan Yoko)."

After being written in a colloquial style, the "Draft for a Revised Constitution" was submitted at a plenary session of the Privy Council (Sumitsu In) on April 17. In the course of deliberation, the prime minister Kijuro Shidehara resigned and this draft was withdrawn. After a new prime minister

(17) Three basic points stated by Supreme Commander to be "musts" in Constitutional revision.

I. Emperor is at the head of the state.

His succession is dynastic.

His duties and powers will be exercised in accordance with the Constitution and responsive to the basic will of the people as provided therein.

II. War as a sovereign right of the nation is abolished. Japan renounces it as an instrumentality for settling its disputes and even for preserving its own security. It relies upon the higher ideals which are now stirring the world for its defense and its protection.

No Japanese Army, Navy, or Air Force will ever be authorized and no rights of belligerency will ever be conferred upon any Japanese force.

III. The feudal system of Japan will cease.

No rights of peerage except those of the Imperial family will extend beyond the lives of those now existent.

No patent of nobility will from this time forth embody within itself any National or Civic power of government. Pattern budget after British system.

(18) Id.

(19) The records shows that after this meeting, Matsumoto drafted again with some corrections, but it was rejected again by $\mathrm{GHQ}$.

(20) The record by GHQ wrote the following. "Through his interpreter Dr. Matsumoto said that he had read the draft and understood it but that it was so vastly different from their own draft that it would be necessary to present it to the Prime Minister before any statement could be made by him." Later Matumoso prepared one explanation of his draft. His suggestion was rejected by GHQ. 
Yoshida took his office, the draft was approved at the Privy Council on June $8^{\text {th }}$ except objection by Minobe.

The "Bill for Revision of the Imperial Constitution" was submitted to the Imperial Diet under Article 73 of the Meiji Constitution. Although this amendment involved a big change in the sovereignty from the emperor to the Japanese people, the amendment was proposed to the Imperial Diet. A committee and sub-committee for this draft were created to discuss this bill. After the deliberation of some minor changes, this bill received the emperor's sanction.

The new Japanese Constitution was promulgated on November 3 in 1946 and put into effect on March 3 in 1947. In this historical review, the Japanese government had formulated several drafts of the Japanese Constitution, including the Matsumoto Draft, MacArthur Draft, March 2 Draft, and March 5 Draft (March 6 Draft in English). In the next chapter, I will focus on provisions for extraordinary tribunals in these drafts. ${ }^{(21)}$

3. Extraordinary Tribunal Provision in Drafting Procedures

In the Matsumoto Draft, there was a text of extraordinary tribunals. The "Gist of the Revision of the Constitution," written by the GHQ on Febru$\operatorname{ary} 8^{\text {th }}$, noted that “Article 81 shall be revised so as to provide that litigations involving administrative matters shall come within the jurisdiction of Courts of Law (i.e., rather than of Courts of Administrative Litigation) in accordance with other laws governing such matters."

Article 68 in the MacArthur Draft contained the following: “A strong and independent judiciary being the bulwark of the people's rights, the whole judicial power is vested in a Supreme Court and in such inferior courts as the Diet shall from time to time establish. No extraordinary tribunal shall be established, nor shall any organ or agency of the Executive be given final judicial power. All judges shall be independent in the exercise of their con-

(21) For provision of these drafts, see Shouetsu MATSUMOTO, Genten Nihon Kenpo Siryoshu (Souseisha 1988).

Underlined parts were added by author 
science and shall be bound only by this Constitution and the laws enacted pursuant thereto."

This draft written in English was submitted to the Japanese government on February 13, and a translated draft in Japanese was handed to the Cabinet on February 25, just before the Cabinet meeting.

The March 2 Draft was written in Japanese, and it stated in Article 79 that "the judiciary exercises its power independently. The whole judiciary power is vested in a Supreme Court and in such inferior courts as the Diet shall establish. No extraordinary tribunal shall be established." Further, Article 80 noted that "A Supreme Court is final tribunal."

The March 5 Draft (in Japanese) and March 6 Draft (in English) stated the following in Article 72: "The whole judicial power is vested in a Supreme Court and in such inferior courts as the Diet shall establish. No extraordinary tribunal shall be established, nor shall any organ or agency of the Executive be given final judicial power."

These modifications between the GHQ and the Japanese government were negotiated in English by comparing the Japanese draft with that of the English. In order to have a better understanding, I examine the records of this session between the GHQ and the Japanese government, which show that Whitney spoke English very slowly and occasionally stopped for intervals.

Especially for extraordinary tribunals during these sessions, the GHQ asked once the reason behind the Japanese government's request to delete the text, "being the bulwark of the people's rights." In response, the Japanese government said that this text was a kind of a figurative expression and did not fit in the Japanese text, and the usage of the word "whole" conveyed the necessary meaning.

The Japanese government further elucidated that because the term "whole" implied that administrative agencies could not exercise judicial power, it was not necessary to include the following text: "No extraordinary tribunal shall be established, nor shall any organ or agency of the Executive be given final judicial power." The GHQ consented to this proposal for a 
short period. During this time, the GHQ reconsidered the proposal and insisted that the sentence on "extraordinary tribunals" be retained.

Once again, the Japanese government pointed out that if this text was included, the Japanese Constitution could not establish the family court and juvenile court like the ones in the U.S. court system. To this, the officials at the GHQ did not give them a clear response. The record noted that owing to this uncertain attitude of the GHQ, the Japanese government thought that even though this text left untouched, there were some possibilities of interpretation of this Article to create some tribunals. ${ }^{(22)}$

In this chapter, the draft of Japanese Constitution is introduced. It looks like GHQ might expect that only judiciary in new Constitution protects the rights of the people. In any case, it is impossible to see the precise intent of the drafters. Records of the meeting and drafts of the Japanese Constitution do not provide us with a definite idea to answer the question at hand: Why do the Japanese need an extraordinary tribunal for the IP court or environmental law court? It is difficult to comprehend why the GHQ retained the sentence on "extraordinary tribunals," and why the Japanese government did not pose any objection and left it untouched. In any case, soon after the promulgation of the Japanese Constitution, new requirements for the establishment of special tribunals arose.

\section{Present-day Extraordinary Tribunals in Japan}

\section{Why Do We Need Special Courts?}

Because the Meiji Constitution followed the model of the European court system, the power of the administrative court was regarded as administrative, and not judicial. The establishment of an administrative court was not prohibited under the Meiji Constitution.

In the Japanese Constitution, however, the setting up of an extraordinary

(22) Supra note 16, Tatsuo SATO, 138, 266-9. 
tribunal is prohibited in Article 76. As the Japanese drafters of the Japanese Constitution expected at the sessions with the GHQ, there were certain possibilities that "extraordinary tribunals" would be interpreted. I can confirm one fact that the Japanese Constitution followed the U.S. Constitution and clearly prohibited the establishment of an extraordinary tribunal in Article 76. After the Japanese Constitution was put into effect, there were several cases that required the application of specific knowledge, expertise, experience and giving flexible remedies. This was because in the general judicial court, providing a remedy was time consuming, and this process also required certain special knowledge and skills. Professional judges are legal experts; however, they lack some non-legal technical knowledge. Although a more flexible remedy is required in some cases, the main task of the judge is to write a decision. ${ }^{(23)}$

2. Is It Permissible to Set Up an Extraordinary Tribunal ?

Professor Minobe, who was a blind believer in the Meiji Constitution, maintained that judicial power even under the Japanese Constitution was designed to include only civil and criminal cases, not administrative ones. Thus, the judicial power in the Japanese Constitution should be treated as it was in the Meiji Constitution. ${ }^{(2)}$ Today, his theory is not accepted any more by professors of Japanese constitutional law for the following reasons. ${ }^{(25)}$

First, unlike the Meiji Constitution, the Japanese Constitution had no Article 61 that specially provided for an administrative court.

Second, if we accept Minobe's theory, we would fail to provide sufficient remedies to administrative cases. The Meiji Constitution also experienced in-

(23) After judicial reform in 1999, specialized court such as medical malpractice was discussed. This medical malpractice courts is in judicial power.

(24) MINOBE, at 502. Tatsukichi MINOBE, Kenpo-Seigi, 568-61, 580. Shinpei Eto contributed the creation of the original judicial courts. At the beginning, judicial court belonged to the administrative power.

(25) Toshiyoshi MIYAZAWA, revised by Nobuyoshi ASHIBE, Zentei Nihon Koku Kenpo (Nihon Hyoron Sha 2005), 591-613. 
sufficient remedies for administrative cases, and several bills for revision of administrative courts were sent to the Imperial Diet.

Third, Article 81 in the Japanese Constitution provides a system of judicial review. However, it took for granted that the judicial court reviews administrative cases.

Fourth, the provision for the right of access to the court means that people have the right to get their petition heard by judges who are designated and appointed by the law. If people are faced with judges who are not selected by law and if the decision at the administrative court differs from that at the judicial court, there would be a conflict of decisions. If the outcome is subjected to which court the petition is heard, it would be against democracy and equal protection of law.

Fifth, the definition of an extraordinary tribunal is important. If we define the prohibition of an extraordinary tribunal as a court that exercises "exclusive" jurisdiction over certain cases "independent" of general courts, then the family court and IP court would be acceptable provided the losing party has the right to appeal in the judicial hierarchy. Today, for family and IP case, the family and IP courts are specialized in the system of general court for family and IP issues and cases are heard by judicial judges, not by administrative judges without tenured position.

3. Independent Administrative Agency under the Japanese Constitution

In order to provide a speedy decision and flexible remedy, under the Japanese Constitution at present, people need not take their petitions only to the court. There are other places that provide remedy outside judiciary. Article 76 provides that "No extraordinary tribunal shall be established, nor shall any organ or agency of the Executive be given final judicial power."

On reading this article carefully, one plausible interpretation can be discerned, that is, the establishment of an administrative agency or commission for adjudication is permitted as long as its adjudication is not "final." This interpretation is not against the Constitution's Article 76 so long as the final tribunal is the sole Supreme Court, and a losing party at administrative com- 
missions may appeal to the general court system.

Even though this interpretation is permissible, another issue comes into play. At the administrative agency, certain evidence is submitted and approved for adjudication. However, during appeal at the judicial court, it is questionable whether this substantive evidence presented at the administrative agency binds the decision of the judicial court.

In order to solve this problem, one possible idea that can be put forth is that the core of judicial power lies in the application of law to the fact, and not the evidence. If this is the case, substantive evidence rule would not be against the Constitution. This interpretation is permissible because the procedure at the administrative agency is based on a quasi-judicial one and an appeal to the general court is allowed. It is certainly unacceptable that factfinding by the agency blindly binds the decision made by the judicial court. The decision to adopt the evidence presented at the agency in the judicial court should be left to the judiciary in any case. ${ }^{(26)}$

Today, it is said that remedy provision at the court takes a long time and resources are wasted in certain cases. Some cases need a flexible adjudicator possessing special knowledge and experience. In response to these needs, special tribunals in the judiciary and administrative commission in the Cabinet were established by the law.

For example, in environmental pollution cases, the contamination is widespread and multiple parties are involved. Flexible inexpensive remedies are required in such cases. In Japan, some environmental cases are heard in an administrative commission called Environmental Dispute Coordination Commission (EDCC) at the Ministry of Internal Affairs and Communications.

4. EDCC and IP court

In order to render a flexible, quick, and inexpensive remedy, the Japanese Constitution offers two options. One is the administrative commission in ad-

(26) Koji SATO, Kenpo (Third edition), (Seirinshoin 1997), 307. See also, Isao SATO, Pocket Chushaku Kenpo (Ge), (Yuhikaku 1984), 964. 
ministrative power. The other is a special section of the court system within the judicial power. EDCC is an administrative commission that does not belong to the judicial power. This administrative agency was established in 1972. The members of the EDCC are appointed by the prime minister with the consent of the Diet. The EDCC has one chairman and six commissioners. The proceedings in the EDCC start with a complaint submitted by the party. The committees are required to be neutral when dealing with adverse parties like the judges in a judiciary. The party is allowed to use expert opinion. The EDCC proceedings are similar to the judicial court proceedings. People are offered cheaper, quicker, and easy-to-access remedies that are more flexible than the ones in formal court proceedings. The EDCC may offer both the parties a plan of meditation and ask them to accept it. As the judiciary has family courts all over Japan, the parties may consult the Pollution Examination Commission (PEC; Kogai Shinsa Kai) in each prefecture.

The IP High Court used to be one of the sections of the general court system. At present, it is a specialized body and is located in the Tokyo High Court and Osaka High Court. These courts handle IP-related cases and function as appeal courts from the district court and administrative agency, namely, the Japanese Patent Office. ${ }^{(27)}$ Originally, this court was just one of the civil sections of the high court. After the breakdown of the Japanese economy, the attention of the general public was drawn toward the IP cases. Following judicial reform in the late 1990s, the IP court was put into effect in 2005.

(27) For the appeal to the general court, Administrative Complaint Law (Gyosei Fufuku Sinsa Hou) is provided. Except special provision by statutes, a person who argues he is infringed needs to bring action to the administrative agency before the court.

For the case about technology issue, for example IP case, the first court is Osaka and Tokyo district court. For the case about non-technology issue, the first court is all of the district courts.

In environmental pollution cases, the general court is available in the first instance. 
5. Is the Independent Administrative Commission Unconstitutional?

Most petitions for environmental disputes are filed to administrative commissions in the first instance. These commissions are called independent administrative agencies. These agencies work as quasi-judicial and quasi-legislative organizations. They promulgate regulations and adjudicate some cases assigned by statutes. In order to adjudicate politically neutral decisions, these agencies are independent of political pressures from executive power and legislative power. The constitutionality issue happens if the independent administrative agency goes against the Constitution.

Separation of powers is maintained under the parliamentary system of the Japanese Constitution. The prime minister is selected in the Diet as the highest person in the Cabinet. ${ }^{(28)}$ Unlike the Meiji Constitution, the prime minister under the Japanese Constitution must appoint the majority of ministers from among the members of the Diet. If a vote of non-confidence is passed in the Cabinet, the Cabinet needs to resign or dissolve the Diet. ${ }^{(29)}$ In this parliamentary system, the independent administrative agency exists in executive power and is separated from the order of the cabinet and the parliament.

It is argued that the independent administrative agency is unconstitutional. Because this agency is not controlled by the Cabinet, it is neither responsible to the executive power nor the legislative power. Today, however, the Japanese government has established several independent administrative agencies according to the following counterargument.

This counterargument states that the executive power may require certain field such as National Personnel Agency, Fair Trade Commission, National Public Safety Commission, Public Security Examination Commission and EDCC that the decision be politically neutral and be separated from the political pressure of the Cabinet and parliament. Under the parliamentary system, the Cabinet and the parliament are dissolved very often. In some

(28) Article 6, 66 and 72 of the Japanese Constitution.

(29) Article 69-71 of the Japanese Constitution. 
field, a long-term deliberation with political neutrality is required. Since the Japanese Constitution supports democracy, the appointment of commissioners supplements the legitimacy of democracy in the Diet by appointment and control of budget even though the control of the independent agency by the Cabinet is insufficient. Today, the independent administrative commission and special courts function to provide flexible and speedy remedies in Japan. ${ }^{(30)}$

\section{Conclusion}

As observed in other countries, the creation of an environmental court is discussed. Should the Japanese government structure follow this current trend to create an environmental court in the judiciary?

It is evident from the drafting history of the Japanese Constitution that the Meiji Constitution had an extraordinary tribunal in administrative power, independent of judicial power. Following the European court system, administrative courts existed in Meiji Constitution.

Today, following the model of the U.S Constitution, the Japanese Constitution prohibits extraordinary tribunals. It is not clear to imagine that the GHQ and Japanese government had a particular intent about the present-day special courts such as family court, juvenile court, and IP court or EDCC. After WWII, however, the emergence of certain needs require rapid, flexible, and expert decisions in hearings. In order to fulfill with these needs, there are two options under the Japanese Constitution.

The first option is to create a special court in the judiciary. A special court is permissible as long as it is under the hierarchy of the judicial court system and allows for appeal. The IP court is a result of this option.

The second option is to set up an independent administrative agency in

(30) Another issue is fairness of the adjudication because in administrative power the lower agency is in chain of command by the higher agency. 
the executive power. Although it is separated from the parliament and the Cabinet to some extent for political neutrality, it is permissible as long as the power of appointment and budget is in the hands of the Cabinet and the Diet.

At present, the Japanese people need to demand the establishment of a special court in the judicial power and an administrative agency in the executive power to check if they really need to create a special court for certain cases in the judicial power or executive power.

\section{[Appendix]}

The Matsumoto Draft, there was a text of extraordinary tribunals. This was written in Japanese.

The "Gist of the Revision of the Constitution," written by the GHQ on February 8th, noted that "Article 81 shall be revised so as to provide that litigations involving administrative matters shall come within the jurisdiction of Courts of Law (i.e., rather than of Courts of Administrative Litigation) in accordance with other laws governing such matters."

Article 68 in the MacArthur Draft contained the following: "A strong and independent judiciary being the bulwark of the people's rights, the whole judicial power is vested in a Supreme Court and in such inferior courts as the Diet shall from time to time establish. No extraordinary tribunal shall be established, nor shall any organ or agency of the Executive be given final judicial power. All judges shall be independent in the exercise of their conscience and shall be bound only by this Constitution and the laws enacted pursuant thereto."

The March 2 Draft was written in Japanese, and it stated in Article 79 that "the judiciary exercises its power independently. The whole judiciary power is vested in a Supreme Court and in such inferior courts as the Diet shall establish. No extraordinary tribunal shall be established." Further, Article 80 noted that "A Supreme Court is final tribunal." 
The March 5 Draft (in Japanese) and March 6 Draft (in English) stated the following in Article 72: "The whole judicial power is vested in a Supreme Court and in such inferior courts as the Diet shall establish. No extraordinary tribunal shall be established, nor shall any organ or agency of the Executive be given final judicial power."

(Underlined parts in this paper were added by author) 